CLINICAL HEMORHEOLOGY, Vol. 12, pp. 497-498, 1992

$0271-5198 / 92 \$ 5.00+.00$ Printed in the USA.

Copyright (c) 1992 Pergamon Press Ltd. All rights reserved.

\title{
CONTENTS OF BIORHEOLOGY, VOLUME 29, NUMBER 1
}

VOLUME 29, NUMBER 1

1992

ABSTRACTS

Eighth International Congress of Biorheology

Yokohama, Japan

3-8 August 1992

DAILY PROGRAM

<August 4 (Tue)>

PLI Biorheology: present and future developments

Polseuille Award Ceremony and Lecture

S 1 Biorheology of cell adhesion and aggregation

$S 2$ Microrheology of leukocytes in vivo and in vitro

S 3 Erythropoietin: hemorheology and hemodynamics

$S 4$ Mechanics of venous system

F 1 Microcirculation 1

F 2 Vessels

F 3 Cerebrovascular diseases

F 4 Cells and molecular biorheology

P 1 Clinical hemorheology

$<$ August 5 (Wed) >

PL2 Molecular mechanism of stimulus-secretion coupling in exocytosis

S 5 Blomechanics of interstitium and 1 ymph vesse

S 6 Rheology of biopolymer gels

S 7 Biorheology in near zero gravity

$S 8$ Biorheology in coronary circulation

S 9 Molecular biology in biorheology

F 5 Clinical hemorheology I

F 6 Blood rheology 1

F 7 Pharmacology

F 8 Hemodynamics

F 9 Clinical hemorheology 11

Fio Microcirculation II

P 2 Biosolids and bioliquids

<August 6 (Thu)>

PL3 Shear stress and mechanical strain effects on endothelial cell metabolism and function

S10 The effects of diabetes on the flow properties of blood and the behavior of its formed elements

sil Fluid mechanics and biology of endothellal cells

FIl Biofluids and biopolymers

F12 Rheology of red blood cells 
(Continuation of Contents)

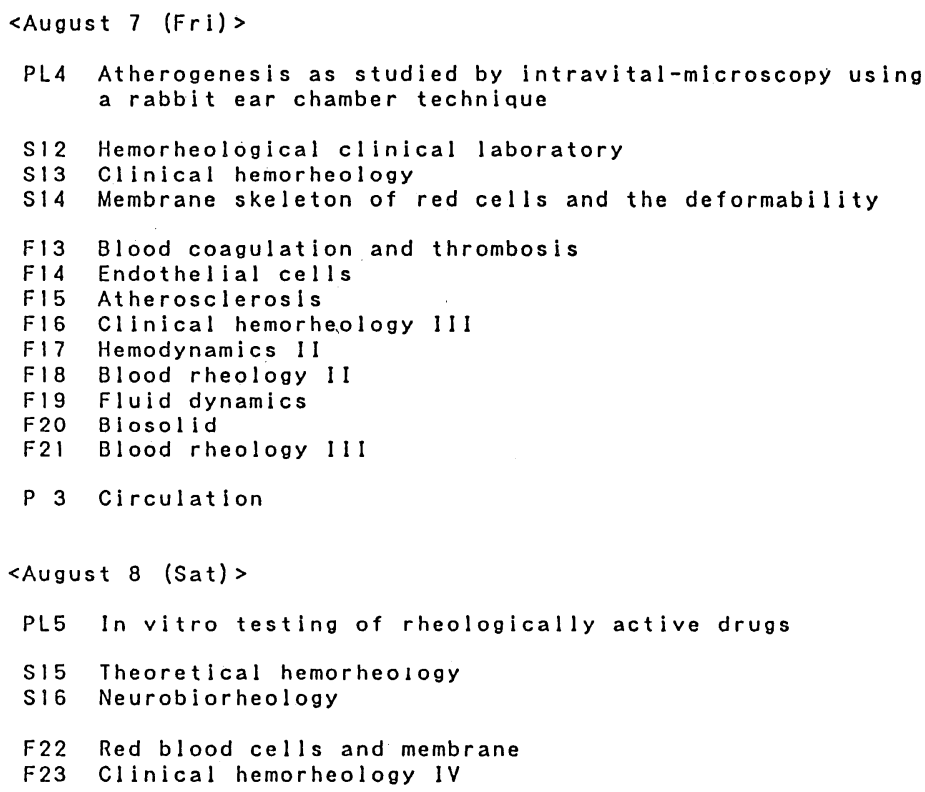

